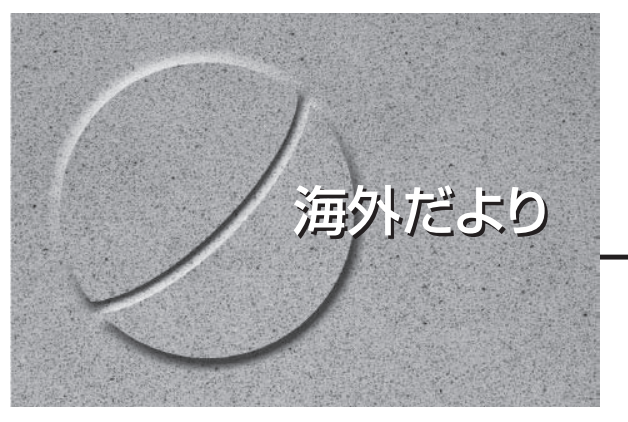

\title{
スイスの放射性廃棄物処分関係 機関に帯在して
}

半井 健一郎 ${ }^{*}$

\section{1.はじめに}

2009 年の 4 月からの約半年間，スイスに長期滞在す る機会がありましたので，滞在先などについてご紹介を させていただきます。

私の滞在先は, Nagra（放射性廃衰物管理協同組合） とPSI（ポール・シェラー研究所）でした。いずれも原 子力分野では世界的にも有名な機関ですが, コンクリー 卜分野では認知度が高いとはいえないと思いますので, まずはそれぞれをご紹介します。

\section{Nagra（放射性廃棄物管理協同組合）}

Nagra（読みはナグラ）は, 原子力発電によって発生 する放射性廃棄物の安全管理を目的に, 原子力発電会社 とスイス連邦によって，1972 年に設立されました。本 社は, チューリッヒから北西に約 $20 \mathrm{~km}$ のバーデン近 郊にあります。廃棄物の管理・処分方法の立案, 実行の ため, 地層処分計画の作成, 地層調査の実施, 処分地の 安全評価, 一般市民への広報, 国際共同研究の推進など を行っています。スタッフは約 100 名で, 地質と安全, 技術と現地調査, 放射性物質, 国際協力などの部門から なります。スイスの廃棄物処分におけるセメント系材料 の役割は限定的であるため, Nagraにおける当該分野の 担当者は数名で, しかも転職後に勉強を始めたというよ うな人もいました。

日本でも, 放射性廃棄物の処分は重要な課題であり, セメント系材料の性能をより積極的に議論している処分 方法もあります。低レベル放射性廃棄物については日本 原燃(株)が, 高レベル放射性廃衰物と一部の低レベル放射 性廃棄物（TRU 廃棄物）については原子力発電環境整 備機構（NUMO）がそれぞれ担当しています。スイス ではあらゆる放射性廃棄物を Nagra が一括して扱って いるのに対し，日本は役割分担を行っており，こんなと ころにもお国柄の違いが反映されているように思いま す。ちなみに, スイスの発電における原子力の割合は日 本とほぼ同じ 3 割ですが, 残りの 7 割は水力です。

Nagra は国際的な共同研究を積極的に展開しています

* なからい・けんいちろう/群馬大学大学院 工学研究科 准教授 (正会員)

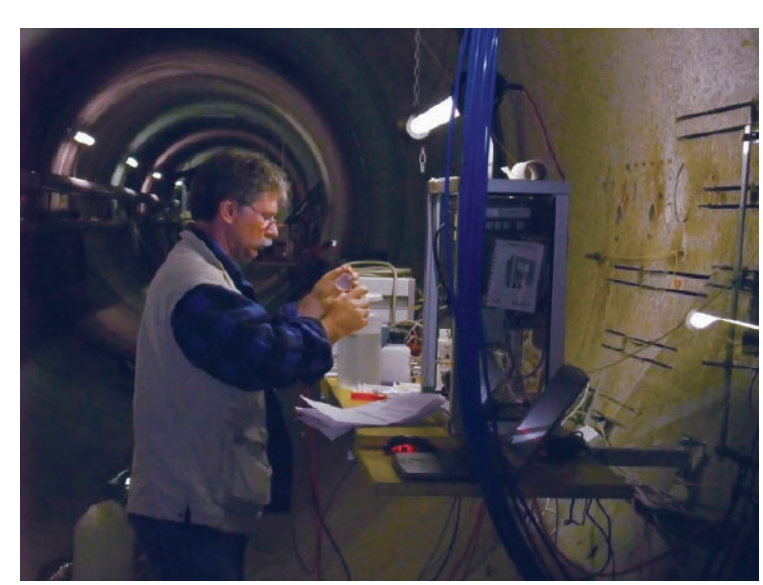

写真-1 地下研究所での実験風景

が，その活動の場となるのがグリムゼル試験場とモンテ リ岩盤研究所の 2 つの地下施設です。特に, 昨年 25 周 年を迎えたグリムゼル試験場は Nagraの施設であり（モ ンテリ研究所は国の施設), 岩盤中の物質移行やベント ナイトによるバリア性能の評価など, 廃棄物処分のため の広範な研究が行われています (写真-1)。アルプス山 中の水力発電所へのアクセストンネルを利用して建設さ れており, 地表面下 $450 \mathrm{~m}$, 標高 $1750 \mathrm{~m}$ に位置します。 地下 $450 \mathrm{~m}$ に位置する地下研究所ということになります が，訪問するには相当に山を登ることになります。

\section{PSI（ポール・シェラー研究所）}

PSI はスイスにおける科学技術分野における最大の研 究機関で, 1988 年に設立されました。研究所の名前は著 名なスイス人物理学者に由来します。主たる研究対象は, 物質の構造, エネルギーと環境, 健康の 3 領域で, 大型 加速器の運用も行っています。Nagra 本社から北西約 $20 \mathrm{~km}$ のライン川の支流アーレ川沿いに位置し, 約 1300 名のスタッフがいます。4つあるスイス連邦の直属の国 立研究機関のひとつで, ほかには, コンクリート分野で も有名な EMPA（材料科学技術研究所）が含まれます。 ちなみに，国立の大学はETH と EPFLの 2 校です。

私が滞在したのは, 廃衰物管理の研究室（Laboratory for Waste Management ; LES) でした。地球化学モデ ル, 粘土吸着メカニズム, 物質移行, 拡散プロセス, セ メントシステムのグループがあり, 研究室全体で約 20 
名の研究員と 6 名の技官, 6 名の博士課程の学生あるい はポスドクがいました。研究分野の性格上, Nagra との 密接な関係があり, Nagraでの課題解決のために必要と なる研究を担当しています。滞在中，グループ間あるい は研究者間での活発な議論が印象的でした。たとえば, 人工バリアの化学的変質の解析評価に関係する, 化学反 応モデル, 移動モデル, 解析コードの各開発担当者が, それぞれの立場から相手の研究を厳しく評価しながら, 必要な開発項目の調整を行っていました。白熱すると議 論はすぐに数時間を超え，途中からは英語解説のないド イツ語だけになるのが常でした。

\section{4. マイヤールの橋}

処分の話から離れますが，スイスのコンクリート構造 物といえば，やはりロベール・マイヤールの橋梁です。代 表作であるザルギナトーベル橋（1930 年）は何度か訪 問をしましたが，特に晴れた日には，急峻な谷と青い空 の中に架かる白い橋が非常に映え，まさに景観と一体化 した美しい構造物であると感じられました（写真-2）。現 地には充実した案内板やパンフレットが整備されていて, この構造物が大切にされていることがよく分かります。 定期的に行っているという撥水剤の塗布作業（写真-3） にもたまたま遭遇し，維持管理にも力を入れていること が分かりました。

マイヤールの橋はほかにもいくつも現存しているので すが，私が訪問した範囲では案内板はどこにでもありま した。架け替えられてしまったものもありますが，ウア ルチール橋（1925 年）のように新橋建設後も歩道橋と して保存されているものもあり ${ }^{1)}$, 歴史的構造物に対す る高い意識を感じました。また，たいていの橋は訪問す るのが容易ではない山奥にあり，当時の最新技術が厳し い条件からスタートしたのだろうと思わずにはいられま せんでした。

\section{5.おわりに}

実際に半年ほどスイスに滞在して，欧州内の地理関係 を生かしたフットワークの軽さ，ネットワークの強さを 実感しました。たとえば，昼からのフィンランドのへル シンキでの会議に参加するのに，スイスからもイギリス からも当日の朝の出発でした。我々の分野では, EPFL

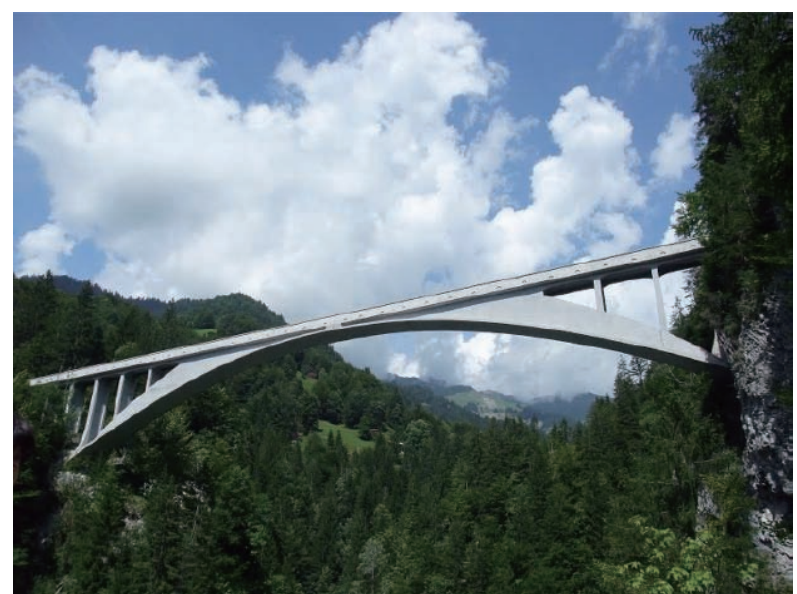

写真-2 ザルギナトーベル橋

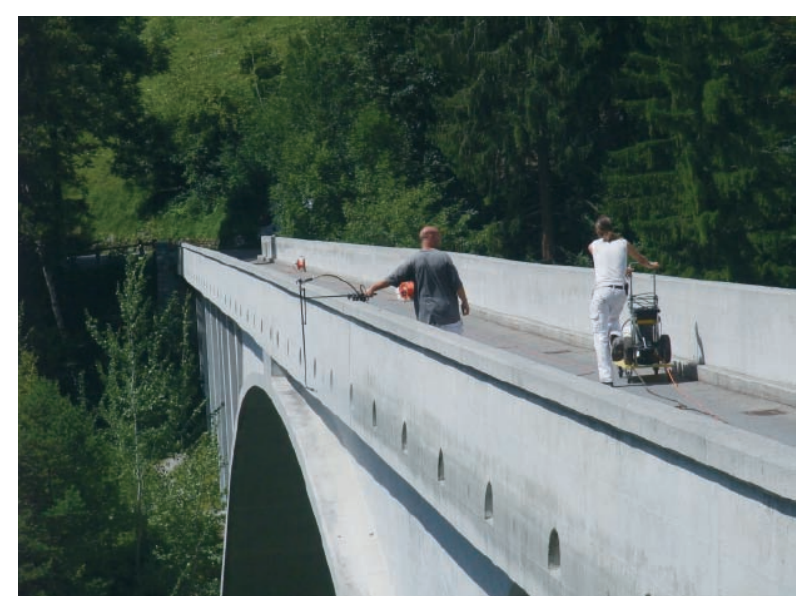

写真-3 ザルギナトーベル橋での撥水剂塗布作業

のScrivener 教授が主宰する Nanocem のプロジェクト が欧州で精力的に活動していますが，毎月直接に集まる ことができることを前提としたメンバー構成というの も，その推進力だと理解できます。日本は地理的には欧 州から離れているところにありますので，積極的な情報 収集や情報発信が必要とあらためて認識しました。

最後になりますが，今回の長期海外滞在にご協力をい ただいた関係各位に、この場をお借りして心より御礼を 申し上げます。

\section{参考文献}

1） 辻 幸和・半井健一郎：マイヤールのファルチールアーチ橋の保 存と新設橋, プレストレストコンクリート, Vol.52, No.1, 2010 